\begin{tabular}{|c|} 
Jurnal Keolahragaan \\
Volume 4 - Nomor 1, April 2016, (74 - 84) \\
Tersedia online: http://journal.uny.ac.id/index.php/jolahraga
\end{tabular}

\title{
PENGEMBANGAN MODEL PERMAINAN UNTUK PEMBELAJARAN KINESTETIK PADA
} ANAK TUNANETRA

\author{
Riza Efriyanti ${ }^{1)}$, Sumaryanti ${ }^{2)}$ \\ ${ }^{1}$ Jl. Tanjung Raya 2 Komp. Pesona Parma Blok D No.6 Pontianak. Email: riza_efriyanti@yahoo.com \\ ${ }^{2}$ Pendidikan Kesehatan dan Rekreasi, Universitas Negeri Yogyakarta. Jalan Colombo No 1, \\ Karangmalang Yogyakarta 55281, Indonesia. Email: sumaryanti@uny.ac.id
}

\begin{abstract}
Abstrak
Penelitian ini bertujuan untuk menghasilkan model permainan untuk pembelajaran kinestetik pada anak tunanetra. Pengembangan ini dimodifikasi menjadi dua tahap, yaitu: tahap pendahuluan dan tahap pengembangan. Tahap pendahuluan meliputi (1) melakukan kajian literatur; (2) penelitian relevan; (3) observasi; dan (4) studi pendahuluan. Tahap pengembangan meliputi (1) mengembangkan produk awal; (2) validasi ahli; (3) uji coba skala kecil; (4) uji coba skala besar \& uji efektivitas; dan (5) produk operasional. Uji coba skala kecil dilakukan kepada 13 anak di SDLB-A Yaketunis. Uji coba skala besar dan uji efektifitas dilakukan kepada 22 anak di SDLB-A Yaketunis, SLB Negri 1 Bantul, dan SLB Negri 1 Kulon Progo. Uji efektifitas menggunakan pra-eksperimen dengan one group pretest-posttest. Instrumen pengumpulan data mengunakan kuesioner/angket, lembar observasi dan lembar penilaian permainan. Untuk menganalisis data digunakan teknik analisis data skala Guttman. Hasil akhir dari penelitian adalah sebuah produk berupa model permainan untuk pembelajaran kinestetik pada anak tunanetra. Permainan ini memainkan 6 permainan yaitu: (1) permainan temukan teman, (2) permainan balpin, (3) permainan kereta suara, (4) permainan halangan bunyi, (5) permainan balon zig-zag, dan (6) permainan lingkaran ceria. Hasil uji keefektifan didapatkan bahwa keenam model permainan dinyatakan efektif. Model permainan dikemas kedalam sebuah buku panduan dan DVD.
\end{abstract}

Kata Kunci: pengembangan, modelpermainan, kinestetik, anak tunanetra

\begin{abstract}
This study aims to produce a model of kinesthetic learning games for children with visual impairment. This development research is modified into two stages: a preliminary stage and development stage. Preliminary stage includes (1) conducting a literature review; (2) relevant research; (3) observations; and (4) a preliminary study. Stages of development include (1) developing initial products; (2) expert validation; (3) small-scale trials; (4) large-scale trials and effectiveness trials; and (5) operational products. A Small-scale trialwas conducted to 13 children in SDLB-A Yaketunis. Large-scale trials and effectiveness trials wereconducted to 22 children in SDLB-A Yaketunis, SLB Negri 1 Bantul and Kulon Progo SLB Negri 1. Effectiveness trials used a pre-experiment test with one group pretestt-posttest. Instruments of data collection used questionnaires, observation sheets and game ratings sheets. Guttman Scale Data Analysis technique was used to analyze the data. The final result of this study is a product of kinesthetic learning game model for children with visual impairment. Games model on kinesthetic learning is a game model that was designed for visually impaired children inupper class of SDLB specifications. This model plays 6 games, namely: (1) Find A Friend Game, (2) Balpin Game, (3) Sound Train Game, (4) Sound Obstacle Game, (5) Zig-zag Balloon Game, and (6) Cheerful Circle Game. From the effectiveness trials, it is shown that those six games arepractically effective. The model of packed into a guide book and DVD.
\end{abstract}

Keywords: development, game model, kinesthetic, visual impairment children

How to Cite Item: Efriyanti, R., \& Sumaryanti, S. (2016). Pengembangan model permainan untuk pembelajaran kinestetik pada anak tunanetra. Jurnal Keolahragaan, 4(1), 74-84. Retrieved from http://journal.uny.ac.id/index.php/jolahraga/article/view/8134 


\section{PENDAHULUAN}

Anak tunanetra memiliki kemampuan gerak yang sangat terbatas dalam mengikuti pembelajaran gerak seperti pembelajaran pendidikan jasmani di sekolah. Anak tunanetra tidak bisa disamakan perlakuanya dengan anak-anak pada umumnya. Harus ada perlakuan khusus untuk membantu mengurangi keterbatasan pada anak tunanetra. Widjaya (2013, p.87) menyatakan bahwa keterbatasan yang terdapat dalam pembelajaran anak tunanetra antara lain yaitu: (1) keterbatasan dalam konsep dan pengalaman baru, (2) keterbatasan dalam berinteraksi dengan lingkungan, dan (3) keterbatasan dalam mobilitas. Pentingnya pembelajaran berkualitas yang diberikan oleh guru kepada anak-anak tunanetra akan berpengaruh pada kehidupan anak tunanetra. Guru mempunyai peran yang sangat besar terhadap proses pembelajaran yang berkualitas. anak tuananetra memerlukan perhatian yang khusus dari guru dalam melatih kecerdasan kinestetik. Kecerdasan kinestetik yang dimiliki anak tunanetra akan memudahkan anak tersebut melakukan kegiatan sehariharinya dan mengurangi bantuan dari orang lain. Hausstatter \& Nordkvelle dalam Huda (2014, pp. 5-6) mengatakan bahwa pembelajaran merefleksikan pengetahuan konseptula yang digunakan secara luas dan memiliki bayak makna yang berbeda-beda.

Menurut Robert (2001, p. 76) pembelajaran sebagai proses belajar yang dibangun oleh guru untuk mengembangkan kreatifitas berfikir yang dapat meningkatkan kemampuan berfikir siswa, serta dapat meningkatkan kemampuan mengkonstruksi pengetahuan baru sebagai upaya meningkatkan penguasaan yang baik terhadap materi pelajaran. Menurut Surya (2002, p. 4) pada hakekatnya pembelajaran mempunyai tujuan yang ingin dicapai dalam proses pembelajaran. Menurut Daryanto (2005, p. 58) tujuan pembelajaran adalah tujuan yang menggambarkan pengetahuan, kemampuan, keterampilan, dan sikap yang harus dimiliki siswa sebagai akibat dari hasil pembelajaran yang dinyatakan dalam bentuk tingkah laku yang dapat diamati dan diukur. Selama proses pembelajaran, tugas guru yang paling utama adalah mengkondisikan lingkungan belajar agar menunjang terjadinya perubahan perilaku bagi siswa. Karena pada dasarnya guru pemegang peran terpenting dalam proses pembelajaran. Sumiati \& Asra (2009, p. 3) mengelompokkan komponen-komponen pembelajaran dalam tiga kategori utama, yaitu: guru, isi atau materi pembelajaran, dan siswa. Interaksi antara tiga komponen utama melibatkan metode pembelajaran, media pembelajaran, dan penataan lingkungan tempat belajar, sehingga tercipta situasi pembelajaran yang memungkinkan terciptanya tujuan yang telah direncanakan sebelumnya.

Model dalam pembelajaran merupakan suatu konsep yang sangat diperlukan untuk memudahkan dan mencapai tujuan dari pembelajaran tersebut. Model juga digunakan untuk menjelaskan suatu hal dengan mengkonversi hal nyata menjadi lebih komprehensif sehingga mempermudah pengguna. Hal-hal terkait pengembangan model juga harus memperhatikan langkah-langkah dalam melaksanakan pembelajaran (syntax), memiliki tujuan pembelajaran, memiliki aturan, perilaku menyampaikan pembelajaran/permainan, ada perangkat yang membantu dan berperan untuk memperoleh hasil. Salah satu pembelajaran yang baik untuk dilakukan yaitu pembelajaran kinestetik, oleh sebab itu kecerdasan kinestetik penting untuk dilatih.

Menurut Gardner (2001, p. 3) kecerdasan kinestetik yaitu mencakup keahlian-keahlian fisik khusus seperti koordinasi, keseimbangan, ketangkasan, kekuatan, kelenturan dan kecepatan. Kecerdasan kinestetik ditunjukkan oleh kemampuan seseorang untuk membangun hubungan yang penting antara pikiran dan tubuh, yang memungkinkan tubuh untuk memanipulasi objek atau menciptakan gerakan. Kecerdasan ini sangat penting karena bermanfaat untuk (a) meningkatkan kemampuan psikomotorik, (b) meningkatkan kemampuan sosial dan sportivitas, (c) membangun rasa percaya diri dan harga diri, dan (d) meningkatkan kesehatan. Reniq (2009, p. 4) menyatakan kemampuan yang terkait dengan kecerdasan kinestetik jasmani adalah: (a) kemampuan menggerakkan anggota tubuh, (b) kemampuan mengatur keseimbangan tubuh, (c) Kemampuan mengatur kelenturan tubuh, (d) Kemampuan menjaga kesehatan tubuh. Stimulus untuk meningkatkan kinestetik dapat dilatih, ada banyak cara yang dapat dilakukan dan dapat disesuaikan dengan karakteristik anak. secara keseluruhan aktivitas olahrga sanagt berperan untuk meningkatkan kinestetik. Kecerdasan kinestetik dapat dilatih pada setiap anak tampa terkecuali anak yang memiliki keterbatasan seperti anak tunanetra.

Tunanetra adalah kondisi seseorang yang tidak dapat mengunakan indra penglihatanya atau mengalami kebutaan. Menurut Mason \& McCall dalam Widjaya (2013, pp. 18-19) 
menyatakan berdasarkan hasil tes ketajaman penglihatan dengan Snellen Cart, organisasi kesehatan dunia (WHO) mengklasifikasikan penglihatan orang sebagai "normal", "low vision", atau "blind". Ketika seorang anak dengan penglihatan yang normal dapat dengan mudah bergerak di lingkunganya, menemukan mainan dan teman-temanya, serta melihat dan meniru orang tuanya dalam aktivitas seharihari. Anak-anak tunanetra secara harfiah kehilangan saat-saat belajar aktivitas seperti anak normal, hal itu akan berdampak terhadap perkembangan fisik, belajar, keterampilan sosial, dan prilaku. Anak tunanetra memiliki keterbatasan dengan berbagai hal, oleh sebab itu sangat perlu bagi orang tua, guru, dan pakar pendidikan anak tunanetra untuk mengetahui karakteristik anak tunanetara.

Hurwitz (2008, pp. 147-154) mengatakan anak penyandang cacat memerlukan pendidikan khusus dan layanan yang terkait dengan kebutuhan anak itu sendiri. Pendidikan khusus tidak harus selalu pada kelas khusus dan mengelompokan anak tetapi lebih pada pencapaian tujuan dari pendidikan itu sendiri. Ada banyak cara yang bisa dilakukan oleh pendidik agar tercapainya tujua pembelajaran untuk anak salah satunya modifikasi pembelajaran dan sarana prasarana pembelajaran. Pendidiakn untuk tunanetra sangatlah penting, karena keterbelakangan mereka bukanlah hambatan untuk mereka memaksimalkan kemampuan yang dimiliki. Setiap anak mempunyai potensi masing-masing dari situlah tugas guru dan orang tua memberikan pembelajaran yang maksimal untuk mengoptimalkan potensi yang dimiliki anak tunanetra,

Selain kekhususan metode pengajaran yang di gunakan oleh anak tunanetra. Anak tunanetra mempunyai kekhususan dalam menggunakan media pembelajaran. Kurtz, (2008, p. 167) mengatakan kondisi penglihatan anak tunanetra yang tidak berfungsi, maka media yang digunakan untuk pengajaran untuk anak tunanetra ialah medi yang dapat dijangkau dengan pendengaran dan perabaan. Media bantu yang digunakan untuk perndengaran biasanya seperti tape-recorder sedangkan media yang digunakan untuk perabaan dan mempermudah pembelajaran yaitu huruf braille. Bunyibunyian juga sebagai salah satu penunjang alat bantu pembelajaran bagi tunanetraa. Borgesa \& Toméb (2014, p. 19) melalui penelitian yang dilakukan menyatakan bahwa musik dan bunyibunyian dapat merangsang indra pendengaran sebagai alat keseimbangan penyandang tunanetra.

Rencanakan pembelajaran dengan mengingat kebutuhan individual anak terkait dengan penglihatanya. Sunanto (2005, p. 142) menyatakan anak tunanetra dapat dibantu dalam melatih kecerdasanya yaitu dengan: (1) penguasaan keterampilan pendengaran, (2) kesadaran tubuh dan perkembangan motorik, dan (3) eksplorasi lingkungan luar. kebutuhan dan layanan pendidikan untuk anak tunanetra sanagt diperlukan. Proses dan srategi yang digunakan perlu ada penyesuaian dengan karakteristik anak tunantra. Menurut Lowenfeld dalam Smith (2006, p. 9) menidentifikasi empat petunjuk dalam proses pendidiakn anak tunanetra yaitu: (1) prinsip idividual, (2) prinsip pengalaman pengindraan, (3) prinsip totalitas, dan (4) prinsip aktivitas mandiri.

Pendidikan jasmani bermaksud mengembangkan kebugaran jasmani, kebugaran motorik, dan keterampilan motorik dasar. Ruang lingkup pendidikan jasmani terdiri atas tiga domain yaitu kognitif, afektif, dan pisikomotorik. Psikomotorik mempunyai peran yang sangat penting dalam pendidikan jasmnai. Menurut Tarigan (2000, p. 7) program pendidikan jasmani bagi tunanetra bermaksud mengambangkan kebugaran jasmani dan keterampilan motorik yang diperlukan untuk kegiatan seharihari, orientasi dan mobilitas, meningkatkan konsep diri dan penghargaan diri serta keterampilan olahraga. Menurut Sunanto (2005, p. 171) dalam pendidikan jasmani ada beberapa faktor yang memiliki peran penting yaitu: (1) relaksasi, (2) postur dan gerak, dan (3) kebugaran jasmani. Dalam pelaksanan pendidikan jasmani bagi tunanetra perlu melakukan adaptasi dalam hal materi, strategi, dan metode. Modifikasi hal-hal tersebut dapat berupa modifikasi peraturan permainan, teknik, teknik mengajar dan modifikasi lingkungan.

Permainan diartikan sebagai salah satu sarana yang bisa dijadikan sebagai jalan untuk melakukan transformasi ilmu kepada anakanak, (Raisatun, 2012, p. 11). Jadi permainan ada-lah satu aktivitas yang menyenangkan yang dapat dilkukan siapapun untuk kesenangan. Selanjutnya Bell (2005, p. 136) many people think of play as a physical activity, letting off steam and getting rid of surplus energy. Banyak orang berpikir bahwa bermain adalah sebuah aktivitas fisik, melepaskan uap (keringat) dan mendapatkan surplus energi. Anak tunanetra sangat antusias belajar dengan mengunakan 
model permainan karena pada dasarnya mereka tidak merasa sedang belajar melainkan sedang bermain. Ada tujuh manfaat bermain menurut Raisatun (2012, p. 65) yaitu; (1) perkembangan aspek fisik, (2) perkembangan untuk aspek motorik kasar dan motorik halus, (3) perkembangan aspek sosial, (4) perkembangan aspek emosi dan keperibadian, (5) perkembangan aspek kognisi, (6) mengasah ketajaman pengindraan, dan (7) mengambangkan keterampilan olahraga dan menari.

Berdasarkan pendapat di atas permainan merupakan wahanan untuk memberikan berbagai pengalaman bagi anak. Permainan dapat dijadikan media alternatif untuk menyalurkan ilmu kepada anak-anak. Dengan bermain anak dapat bereksplorasi, bereksperimen berbagai pengalaman yang sangat bermanfaat bagi pertumbuhan fisik dan perkembangan keterampilan dan tentunya adalah perkembangan kognitifnya. Bermain dengan berbagai variasinya dapat menggerakkan berbagai anggota tubuh anak yang berarti juga dapat menstimulasi syarafsyaraf yang ada di otak. Otak merupakan pusat pengolahan berbagai informasi yang diterima oleh ke lima panca indera manusia yang berupa stimulasi atau rangsangan. Rangsangan-rangsangan itu akan diolah di otak dan akan diberikan respon yang berbeda pada rangsangan yang berbeda. Hampir semua respon yang diberikan oleh otak merupakan respon gerak tubuh atau angota tubuh. Sebagai contoh, suatu rangsangan yang di terima oleh indera pendengaran karena suatu suara ajakan seseorang, maka orang yang diajak itu akan mersponnya dengan gerak mulut dengan mengatakan tidak mau ikut atau dapat pula direspon dengan gelengan kepala untuk menyatakan tidak mau ikut ajakannya. Itu hanyalah sebagai suatu contoh sederhana bagaimana otak dapat distimulasi melalui berbagai rangsangan terhadap salah satu panca indera. Semakin banyak indera yang distimulasi, semakin banyak pula sel-sel otak yang berkembang. Semakin kompleks bentuk rangsangan yang datang, akan semakin berlipat ganda sel-sel otak yang berkembanga. Itulah bentuk-bentuk suatu permainan yang dapat menjadi arena bermain anak dalam rangka menumbuhkembangkan berbagai kecerdasan anak

Strategi pembelajaran permainan harus dapat memilih pendekatan yang sesuai dengan kebutuhan anak tunanetra. Kebutuhan anak tunanetra dapat di lakukan melalui modifikasi pembelajaran permainan kinestetik. Imbiriba, et all. (2006, p. 181) menyatakan modifikasi pembelajaran permainan kinestetik dapat dilakukan melalui modifikasi alat fasilitas, modifikasi peraturan permainan, modifikasi pendekatan pembelajaran, dan modifikasi variasi keterampilan yang diajarkan. Anak tunanetra sebenarnya bisa mengembangkan kemampuan yang dimiliki dengan bantuan para pendidik. Tugas pendidik hanyalah memodifikasi pembelajaran yang bisa disesuaikan dengan kebutuhan anak itu sendiri.

\section{METODE}

\section{Model Pengembangan}

Penelitian ini merupakan penelitian pengembangan (research and development). Penelitian ini dilakukan untuk mengembangkan model permainan untuk pembelajaran kinestetik pada anak tunanetra dan hasil pengembangan model permainan untuk pembelajaran kinestetik akan dilakukan uji validasi (uji lapangan) terhadap produk hasil pengembangan dengan harapan agar diperoleh model pembelajaran yang efektif, efisien dan menyenangkan serta dapat membantu mengoptimalkan kemampuan kinestetik anak tunanetra.

\section{Prosedur Pengembangan}

Prosedur pengembangan dalam penelitian ini mengadopsi dari tahapan penelitian pengembangan Borg \& Gall (2007, pp. 589-594). Penelitian pengembangan ini dimodifikasi menjadi dua tahap, yaitu: tahap pendahuluan dan tahap pengembangan. Tahap pendahuluan meliputi melakukan kajian literatur, penelitian relevan, observasi, dan studi pendahuluan. Tahap pengembangan meliputi mengembangkan produk awal, validasi ahli, uji coba skala kecil, uji coba skala besar \& uji efektivitas, dan produk operasional.

\section{Desain Uji Coba}

Dalam penelitian dan pengembangan ini, uji coba produk dilakukan tiga tahap yaitu uji skala kecil, uji coba skala besar dan uji keefektifan produk. Pengujian uji skala kecil dan uji coba skala besar menggunakan dua macam bentuk nilai yaitu nilai 1 untuk jawaban "Ya" dan nilai 0 untuk jawaban "Tidak" teknik analisis data ini sering disebut skala guttman. Pengujian keefektifan produk mengunakan penelitian pra-eksperimen dengan desain one group pretestt-posttest design. 


\section{Subjek Uji Coba}

Pada tahap uji coba skala kecil melibatkan 13 orang siswa dengan 2 orang guru. Pada tahap uji coba skala besar melibatkan 22 orang siswa dengan 6 orang guru. Subjek uji coba pada kelompok eksperimen atau uji efektifitas 3 sekolah SLB Yaketunis, SLB Negri 1 Bantul, dan SLB Negri 1 Kulon Progo di DIY.

\section{Jenis Data}

Jenis data dalam penelitian ini adalah kualitatif dan kuantitatif. Data kualitatif diperoleh dari hasil observasi atau pengamatan pembelajaran berupa masukan-masukan dan saran dari ahli dan guru SDLB Tunantra untuk penyempurnaan produk. Selanjutnya data kuantitatif diperoleh dari hasil penilaian plaksanaan dan hasil belajar peserta didik.

\section{Instrumen Pengumpulan Data}

Instrumen pengumpulan data yang digunakan untuk mengumpulkan data dalam penelitian ini terdiri dari: panduan observasi, rubrik penilaian siswa, dan kuesioner pada uji skala kecil dan skala besar. Kemudian instrumen penilaian akan dinilai oleh 4 orang ahli atau expert judgement dan guru pendidikan anak berkebutuhan khusus pada bagian tunantera, guru dianggap perlu sebagai responden karena guru adalah orang yang akan menggunakan model yang disusun (user expert). Sedangkan dalam uji coba lapangan pedoman yang digunakan untuk mengungkap pendapat dari para expert judgement adalah pedoman yang sama. Selanjutnya pada uji skala kecil dan skala besar diambil pula data kuesioner kepada para siswa yang menjadi subjek coba. Pengambilan pendapat dari siswa dapat membantu perbaikan kualitas dari model permainan.

\section{Analisis Data}

Data hasil penelitian yang telah terkumpul, selanjutnya diolah dan dianalisis secara kualitatif dan kuantitatif. Guna penyempurnaan produk dari masukan-masukan dari ahli dan guru mengunakan teknik kualitatif. Validasi data hasil observasi para ahli dan guru terhadap model permainan untuk kecerdasan kinestetik serta kuesioner yang diisi oleh siswa dinilai menggunakan dua macam bentuk nilai yaitu nilai 1 untuk jawaban "Ya" dan nilai 0 untuk jawaban "Tidak" teknik analisis data ini sering disebut skala guttman. Hasil penilaian dari tiaptiap item dijumlahkan kemudian nilai totalnya dikonversikan untuk mengetahui kategorinya. Pengkonversian nilai merujuk pada standar penilaian patokan (PAP). Khusus untuk menilai alat permainan dalam penelitian ini digunakan metode PIECES. Menurut Al-fatah (2007, pp. 51-54) analisis PIECES dilakukan untuk menilai kinerja, informasi, ekonomi, keamanan, efisiensi, dan pelayanan. Menurut Suyanto (2004, p. 46) untuk mendapatkan informasi dari permasalahan yang akan digunakan untuk melakukan penilaian dari sebuah rancangan sistem atau produk dilakukan dengan analisis PIECES (Performance/kinerja, Information/informasi, Economic/ekonomi, Control/keamanan, Efficiency/efisiensi, Services/layanan).

\section{Uji Validitas}

Penilaian model permainan yang telah di validasi oleh ahli dilakukan pengujian validitas guna mendapatkan data yang akurat. Setiap pertanyaan pada masing-masing permainan diberi rentang penilaian 1-4. Data yang diperoleh diuji validitasnya dengan menggunakan bantuan program komputer SPSS 22.0 Version IBM. Didapat seluruh pertanyaan memiliki nilai $\mathrm{r}$ hitung (Corrected Item-Total Correlation) lebih dari $r$ tabeluntuk $n=10$ dan $\alpha=5 \%$ yaitu 0,632 sehingga dikatakan pertanyaa- pertanyaan yang digunakan pada instrument tersebut Valid.

\section{Uji Reliabilitas}

Penilaian model permainan yang telah di reliabilitas oleh ahli dilakukan pengujian validitas guna mendapatkan data yang akurat. Setiap pertanyaan pada masing-masing permainan diberi rentang penilaian 1-4. Didapatkan hasil Alpha Cronbach sebesar 0,883; 0,885; 0,874; 0,857 ; 0,894; dan 0,880 (>0,60) menunjukkan bahwa sinstrumen dalam penelitian ini adalah Reliabel.

\section{HASIL DAN PEMBAHASAN}

\section{Hasil Penelitian}

Validasi dilakukan oleh empat validator yaitu ahli dibidang anak tunanetra, ahli materi kinestetik, dan ahli materi penjaskes. Hasil validasi yang telah dilakukan oleh empat orang ahli akan dituangkan kedalam bentuk Tabel 1 . 
Jurnal Keolahragaan 4 (1), April 2016 - 79

Riza Efriyanti, Sumaryanti

Tabel 1. Hasil Validasi Ahli Terhadap Model Permainan Kinestetik Pada Anak Tunanetra

\begin{tabular}{clccccc}
\hline \multirow{2}{*}{ No } & \multirow{2}{*}{ Model Permainan } & \multicolumn{4}{c}{ Pengamatan } & \multirow{2}{*}{ Hasil } \\
\cline { 3 - 5 } & & Ahli 1 & Ahli 2 & Ahli 3 & Ahli 4 & \\
\hline 1 & Temukan Teman & Baik & Baik & Baik & Baik & Baik \\
2 & Balon Pindah & Baik & Baik & Baik & Baik & Baik \\
3 & Temukan Bunyii & Baik & Baik & Baik & Baik & Baik \\
4 & Halangan Bunyi & Baik & Baik & Baik & Baik & Baik \\
5 & Halang Rintang Balon Dibawa & Baik & Baik & Baik & Baik & Baik \\
6 & Lingkaran Ceria & Baik & Baik & Baik & Baik & Baik \\
\hline
\end{tabular}

Berdasarkan Tabel 1, maka dapat dinyatakan bahwa semua model permainan untuk pembelajaran anak tunanetra dinyatakan baik dengan revisi. oleh karena itu, model permainan siap dilanjutkan untuk di uji cobakan pada uji sekala kecil. Tahap uji coba skala kecil dilakukan dengan 13 peserta didik anak tunanetra di SLB-A Yaketunis jogjakarta dengan 2 orang guru pelaksana jalanya pembelajaran. Uji coba skala kecil dilaksanakan pada saat kegiatan belajar mengajar mata pelajaran olahraga berlangsung di SLB-A yaketunis. Selanjutnya setelah dilakukan penilaian kuisioner terhadap permainan selanjutnya akan disajikan pada Tabel 2.

Berdasarkan Tabel 2 hasil penilaian kuisioner keenam model permainan untuk pembelajaran kinestetik pada anak tunanetra maka dapat disimpulkan bahwa semuanya keenam model permainan tersebut "sangat baik" dilaksanakan oleh guru di sekolah. Selanjuntya hasil penilaian observasi model permainan untuk pembelajaran kinestetik dapat dilihat pada Tabel 3.

Tabel 2. Hasil Penilaian Kuisioner Model Permainan untuk Pembelajaran Kinestetik pada Anak Tunanetra

\begin{tabular}{|c|c|c|c|c|c|c|c|c|}
\hline \multirow{2}{*}{ No } & \multirow{2}{*}{ Model Permainan } & \multicolumn{6}{|c|}{ Pengamatan } & \multirow{2}{*}{ Hasil } \\
\hline & & Ahli 1 & Ahli 2 & Ahli 3 & Ahli 4 & Guru 1 & Guru 1 & \\
\hline 1 & Temukan Teman & $\begin{array}{c}\text { Sangat } \\
\text { Baik }\end{array}$ & $\begin{array}{c}\text { Sangat } \\
\text { Baik }\end{array}$ & $\begin{array}{c}\text { Sangat } \\
\text { Baik }\end{array}$ & $\begin{array}{c}\text { Sangat } \\
\text { Baik }\end{array}$ & $\begin{array}{c}\text { Sangat } \\
\text { Baik }\end{array}$ & $\begin{array}{c}\text { Sangat } \\
\text { Baik }\end{array}$ & $\begin{array}{c}\text { Sangat } \\
\text { Baik }\end{array}$ \\
\hline 2 & Balon Pindah & $\begin{array}{c}\text { Sangat } \\
\text { Baik }\end{array}$ & $\begin{array}{c}\text { Sangat } \\
\text { Baik }\end{array}$ & $\begin{array}{c}\text { Sangat } \\
\text { Baik }\end{array}$ & $\begin{array}{c}\text { Sangat } \\
\text { Baik }\end{array}$ & $\begin{array}{c}\text { Sangat } \\
\text { Baik }\end{array}$ & $\begin{array}{c}\text { Sangat } \\
\text { Baik }\end{array}$ & $\begin{array}{c}\text { Sangat } \\
\text { Baik }\end{array}$ \\
\hline 3 & Temukan Bunyii & $\begin{array}{c}\text { Sangat } \\
\text { Baik }\end{array}$ & $\begin{array}{c}\text { Sangat } \\
\text { Baik }\end{array}$ & $\begin{array}{c}\text { Sangat } \\
\text { Baik }\end{array}$ & $\begin{array}{c}\text { Sangat } \\
\text { Baik }\end{array}$ & $\begin{array}{c}\text { Sangat } \\
\text { Baik }\end{array}$ & $\begin{array}{c}\text { Sangat } \\
\text { Baik }\end{array}$ & $\begin{array}{c}\text { Sangat } \\
\text { Baik }\end{array}$ \\
\hline 4 & Halangan Bunyi & $\begin{array}{c}\text { Sangat } \\
\text { Baik }\end{array}$ & $\begin{array}{c}\text { Sangat } \\
\text { Baik }\end{array}$ & $\begin{array}{c}\text { Sangat } \\
\text { Baik }\end{array}$ & $\begin{array}{c}\text { Sangat } \\
\text { Baik }\end{array}$ & $\begin{array}{c}\text { Sangat } \\
\text { Baik }\end{array}$ & $\begin{array}{c}\text { Sangat } \\
\text { Baik }\end{array}$ & $\begin{array}{c}\text { Sangat } \\
\text { Baik }\end{array}$ \\
\hline 5 & Halang Rintang Balon Dibawa & $\begin{array}{c}\text { Sangat } \\
\text { Baik }\end{array}$ & $\begin{array}{c}\text { Sangat } \\
\text { Baik }\end{array}$ & $\begin{array}{c}\text { Sangat } \\
\text { Baik }\end{array}$ & $\begin{array}{c}\text { Sangat } \\
\text { Baik }\end{array}$ & $\begin{array}{c}\text { Sangat } \\
\text { Baik }\end{array}$ & $\begin{array}{c}\text { Sangat } \\
\text { Baik }\end{array}$ & $\begin{array}{c}\text { Sangat } \\
\text { Baik }\end{array}$ \\
\hline 6 & Lingkaran Ceria & $\begin{array}{c}\text { Sangat } \\
\text { Baik }\end{array}$ & $\begin{array}{c}\text { Sangat } \\
\text { Baik }\end{array}$ & $\begin{array}{c}\text { Sangat } \\
\text { Baik }\end{array}$ & $\begin{array}{c}\text { Sangat } \\
\text { Baik }\end{array}$ & $\begin{array}{c}\text { Sangat } \\
\text { Baik }\end{array}$ & $\begin{array}{c}\text { Sangat } \\
\text { Baik }\end{array}$ & $\begin{array}{c}\text { Sangat } \\
\text { Baik }\end{array}$ \\
\hline
\end{tabular}

Tabel 3. Hasil Penilaian Observasi Model Permainan untuk Pembelajaran Kinestetik pada Anak Tunanetra

\begin{tabular}{ccccccccc}
\hline \multirow{2}{*}{ No } & \multirow{2}{*}{ Model Permainan } & \multicolumn{9}{c}{ Pengamatan } \\
\cline { 3 - 7 } & & Ahli 1 & Ahli 2 & Ahli 3 & Ahli 4 & Guru 1 & Guru 1 & \\
\hline \multirow{2}{*}{1} & \multirow{2}{*}{ Temukan Teman } & Sangat & Sangat & Sangat & Sangat & Sangat & Sangat & Sangat \\
& & Baik & Baik & Baik & Baik & Baik & Baik & Baik \\
2 & Balon Pindah & Sangat & Sangat & Sangat & Sangat & Sangat & Sangat & Sangat \\
& & Baik & Baik & Baik & Baik & Baik & Baik & Baik \\
3 & Temukan Bunyii & Sangat & Sangat & Sangat & Sangat & Sangat & Sangat & Sangat \\
& & Baik & Baik & Baik & Baik & Baik & Baik & Baik \\
4 & Halangan Bunyi & Sangat & Sangat & Sangat & Sangat & Sangat & Sangat & Sangat \\
& & Baik & Baik & Baik & Baik & Baik & Baik & Baik \\
5 & Halang Rintang Balon Dibawa & Sangat & Sangat & Sangat & Sangat & Sangat & Sangat & Sangat \\
& & Baik & Baik & Baik & Baik & Baik & Baik & Baik \\
6 & Lingkaran Ceria & Sangat & Sangat & Sangat & Sangat & Sangat & Sangat & Sangat \\
& & Baik & Baik & Baik & Baik & Baik & Baik & Baik \\
\hline
\end{tabular}


Tabel 4. Hasil Penilaian Alat Model Permainan Untuk Pembelajaran Kinestetik Pada Anak Tunanetra

\begin{tabular}{|c|c|c|c|c|c|c|c|c|}
\hline \multirow{2}{*}{ No } & \multirow{2}{*}{ Model Permainan } & \multicolumn{6}{|c|}{ Pengamatan } & \multirow{2}{*}{ Hasil } \\
\hline & & Ahli 1 & Ahli 2 & Ahli 3 & Ahli 4 & Guru 1 & Guru 2 & \\
\hline 1 & Performance & $\begin{array}{c}\text { Sangat } \\
\text { Baik }\end{array}$ & $\begin{array}{c}\text { Sangat } \\
\text { Baik }\end{array}$ & $\begin{array}{c}\text { Sangat } \\
\text { Baik }\end{array}$ & $\begin{array}{c}\text { Sangat } \\
\text { Baik }\end{array}$ & $\begin{array}{c}\text { Sangat } \\
\text { Baik }\end{array}$ & $\begin{array}{c}\text { Sangat } \\
\text { Baik }\end{array}$ & $\begin{array}{c}\text { Sangat } \\
\text { Baik }\end{array}$ \\
\hline 2 & Information & $\begin{array}{c}\text { Sangat } \\
\text { Baik }\end{array}$ & $\begin{array}{c}\text { Sangat } \\
\text { Baik }\end{array}$ & $\begin{array}{l}\text { Sangat } \\
\text { Baik }\end{array}$ & $\begin{array}{c}\text { Sangat } \\
\text { Baik }\end{array}$ & $\begin{array}{l}\text { Sangat } \\
\text { Baik }\end{array}$ & $\begin{array}{c}\text { Sangat } \\
\text { Baik }\end{array}$ & $\begin{array}{c}\text { Sangat } \\
\text { Baik }\end{array}$ \\
\hline 3 & Ekonomic & $\begin{array}{c}\text { Sangat } \\
\text { Baik }\end{array}$ & $\begin{array}{c}\text { Sangat } \\
\text { Baik }\end{array}$ & $\begin{array}{l}\text { Sangat } \\
\text { Baik }\end{array}$ & $\begin{array}{c}\text { Sangat } \\
\text { Baik }\end{array}$ & $\begin{array}{l}\text { Sangat } \\
\text { Baik }\end{array}$ & $\begin{array}{l}\text { Sangat } \\
\text { Baik }\end{array}$ & $\begin{array}{c}\text { Sangat } \\
\text { Baik }\end{array}$ \\
\hline 4 & Control & $\begin{array}{c}\text { Sangat } \\
\text { Baik }\end{array}$ & $\begin{array}{c}\text { Sangat } \\
\text { Baik }\end{array}$ & $\begin{array}{l}\text { Sangat } \\
\text { Baik }\end{array}$ & $\begin{array}{c}\text { Sangat } \\
\text { Baik }\end{array}$ & $\begin{array}{c}\text { Sangat } \\
\text { Baik }\end{array}$ & $\begin{array}{l}\text { Sangat } \\
\text { Baik }\end{array}$ & $\begin{array}{c}\text { Sangat } \\
\text { Baik }\end{array}$ \\
\hline 5 & Effeciency & $\begin{array}{c}\text { Sangat } \\
\text { Baik }\end{array}$ & $\begin{array}{c}\text { Sangat } \\
\text { Baik }\end{array}$ & $\begin{array}{l}\text { Sangat } \\
\text { Baik }\end{array}$ & $\begin{array}{c}\text { Sangat } \\
\text { Baik }\end{array}$ & $\begin{array}{l}\text { Sangat } \\
\text { Baik }\end{array}$ & $\begin{array}{l}\text { Sangat } \\
\text { Baik }\end{array}$ & $\begin{array}{c}\text { Sangat } \\
\text { Baik }\end{array}$ \\
\hline 6 & Servic & $\begin{array}{c}\text { Sangat } \\
\text { Baik }\end{array}$ & $\begin{array}{c}\text { Sangat } \\
\text { Baik }\end{array}$ & $\begin{array}{c}\text { Sangat } \\
\text { Baik }\end{array}$ & $\begin{array}{c}\text { Sangat } \\
\text { Baik }\end{array}$ & $\begin{array}{c}\text { Sangat } \\
\text { Baik }\end{array}$ & $\begin{array}{c}\text { Sangat } \\
\text { Baik }\end{array}$ & $\begin{array}{c}\text { Sangat } \\
\text { Baik }\end{array}$ \\
\hline
\end{tabular}

Tabel 5. Hasil Penilaian Kuisioner Model Permainan untuk Pembelajaran Kinestetik pada Anak Tunanetra

\begin{tabular}{|c|c|c|c|c|c|c|c|c|c|c|c|c|}
\hline \multirow{2}{*}{ No } & \multirow{2}{*}{ Model Permainan } & \multicolumn{10}{|c|}{ Pengamatan } & \multirow[b]{2}{*}{ Hasil } \\
\hline & & Ahli 1 & Ahli 2 & Ahli 3 & Ahli 4 & Guru 1 & Guru 2 & Guru 3 & Guru 4 & Guru 5 & Guru 6 & \\
\hline \multirow{2}{*}{1} & \multirow{2}{*}{ Temukan Teman } & Baik & Baik & Baik & Baik & Baik & Baik & Baik & Baik & Baik & Baik & Baik \\
\hline & & Sekali & Sekali & Sekali & Sekali & Sekali & Sekali & Sekali & Sekali & Sekali & Sekali & Sekali \\
\hline \multirow{2}{*}{2} & \multirow{2}{*}{ Balin Pindah } & Baik & Baik & Baik & Baik & Baik & Baik & Baik & Baik & Baik & Baik & Baik \\
\hline & & Sekali & Sekali & Sekali & Sekali & Sekali & Sekali & Sekali & Sekali & Sekali & Sekali & Sekali \\
\hline \multirow{2}{*}{3} & \multirow{2}{*}{ Temukan Bunyi } & Baik & Baik & Baik & Baik & Baik & Baik & Baik & Baik & Baik & Baik & Baik \\
\hline & & Sekali & Sekali & Sekali & Sekali & Sekali & Sekali & Sekali & Sekali & Sekali & Sekali & Sekali \\
\hline \multirow{2}{*}{4} & \multirow{2}{*}{ Halangan Bunyi } & Baik & Baik & Baik & Baik & Baik & Baik & Baik & Baik & Baik & Baik & Baik \\
\hline & & Sekali & Sekali & Sekali & Sekali & Sekali & Sekali & Sekali & Sekali & Sekali & Sekali & Sekali \\
\hline \multirow{2}{*}{5} & Halang Rintang & Baik & Baik & Baik & Baik & Baik & Baik & Baik & Baik & Baik & Baik & Baik \\
\hline & Balon dibawa & Sekali & Sekali & Sekali & Sekali & Sekali & Sekali & Sekali & Sekali & Sekali & Sekali & Sekali \\
\hline \multirow{2}{*}{6} & \multirow{2}{*}{ Lingkaran Ceria } & Baik & Baik & Baik & Baik & Baik & Baik & Baik & Baik & Baik & Baik & Baik \\
\hline & & Sekali & Sekali & Sekali & Sekali & Sekali & Sekali & Sekali & Sekali & Sekali & Sekali & Sekali \\
\hline
\end{tabular}

Tabel 6. Hasil Penilaian Observasi Model Permainan untuk Pembelajaran Kinestetik pada Anak Tunanetra

\begin{tabular}{|c|c|c|c|c|c|c|c|c|c|c|c|c|}
\hline \multirow{2}{*}{ No } & \multirow{2}{*}{ Model Permainan } & \multicolumn{10}{|c|}{ Pengamatan } & \multirow{2}{*}{ Hasil } \\
\hline & & Ahli 1 & Ahli 2 & Ahli 3 & Ahli 4 & Guru 1 & Guru 2 & Guru 3 & Guru 4 & Guru 5 & Guru 6 & \\
\hline \multirow[b]{2}{*}{1} & \multirow{2}{*}{ Temukan Teman } & Baik & Baik & Baik & Baik & Baik & Baik & Baik & Baik & Baik & Baik & Baik \\
\hline & & Sekali & Sekali & Sekali & Sekali & Sekali & Sekali & Sekali & Sekali & Sekali & Sekali & Sekali \\
\hline \multirow{2}{*}{2} & \multirow{2}{*}{ Balin Pindah } & Baik & Baik & Baik & Baik & Baik & Baik & Baik & Baik & Baik & Baik & Baik \\
\hline & & Sekali & Sekali & Sekali & Sekali & Sekali & Sekali & Sekali & Sekali & Sekali & Sekali & Sekali \\
\hline \multirow{2}{*}{3} & \multirow{2}{*}{ Temukan Bunyi } & Baik & Baik & Baik & Baik & Baik & Baik & Baik & Baik & Baik & Baik & Baik \\
\hline & & Sekali & Sekali & Sekali & Sekali & Sekali & Sekali & Sekali & Sekali & Sekali & Sekali & Sekali \\
\hline \multirow{2}{*}{4} & \multirow{2}{*}{ Halangan Bunyi } & Baik & Baik & Baik & Baik & Baik & Baik & Baik & Baik & Baik & Baik & Baik \\
\hline & & Sekali & Sekali & Sekali & Sekali & Sekali & Sekali & Sekali & Sekali & Sekali & Sekali & Sekali \\
\hline \multirow{2}{*}{5} & Halang Rintang & Baik & Baik & Baik & Baik & Baik & Baik & Baik & Baik & Baik & Baik & Baik \\
\hline & Balon dibawa & Sekali & Sekali & Sekali & Sekali & Sekali & Sekali & Sekali & Sekali & Sekali & Sekali & Sekali \\
\hline 6 & Lingkaran Ceria & $\begin{array}{c}\text { Baik } \\
\text { Sekali }\end{array}$ & $\begin{array}{l}\text { Baik } \\
\text { Sekali }\end{array}$ & $\begin{array}{l}\text { Baik } \\
\text { Sekali }\end{array}$ & $\begin{array}{c}\text { Baik } \\
\text { Sekali }\end{array}$ & Baik & Baik & Baik & Baik & Baik & Baik & Baik \\
\hline
\end{tabular}

Tabel 7. Hasil Penilaian Alat Model Permainan Untuk Pembelajaran Kinestetik Pada Anak Tunanetra

\begin{tabular}{|c|c|c|c|c|c|c|c|c|c|c|c|c|}
\hline \multirow{2}{*}{ No } & \multirow[b]{2}{*}{ Model Permainan } & \multicolumn{10}{|c|}{ Pengamatan } & \multirow{2}{*}{ Hasil } \\
\hline & & Ahli 1 & Ahli 2 & Ahli 3 & Ahli 4 & Guru 1 & Guru 2 & Guru 3 & Guru 4 & Guru 5 & Guru 6 & \\
\hline \multirow{2}{*}{1} & \multirow{2}{*}{ Performance } & Baik & Baik & Baik & Baik & Baik & Baik & Baik & Baik & Baik & Baik & Baik \\
\hline & & Sekali & Sekali & Sekali & Sekali & Sekali & Sekali & Sekali & Sekali & Sekali & Sekali & Sekali \\
\hline \multirow{2}{*}{2} & \multirow{2}{*}{ Information } & Baik & Baik & Baik & Baik & Baik & Baik & Baik & Baik & Baik & Baik & Baik \\
\hline & & Sekali & Sekali & Sekali & Sekali & Sekali & Sekali & Sekali & Sekali & Sekali & Sekali & Sekali \\
\hline \multirow{2}{*}{3} & \multirow{2}{*}{ Ekonomic } & Baik & Baik & Baik & Baik & Baik & Baik & Baik & Baik & Baik & Baik & Baik \\
\hline & & Sekali & Sekali & Sekali & Sekali & Sekali & Sekali & Sekali & Sekali & Sekali & Sekali & Sekali \\
\hline \multirow{2}{*}{4} & \multirow{2}{*}{ Control } & Baik & Baik & Baik & Baik & Baik & Baik & Baik & Baik & Baik & Baik & Baik \\
\hline & & Sekali & Sekali & Sekali & Sekali & Sekali & Sekali & Sekali & Sekali & Sekali & Sekali & Sekali \\
\hline \multirow{2}{*}{5} & \multirow{2}{*}{ Effeciency } & Baik & Baik & Baik & Baik & Baik & Baik & Baik & Baik & Baik & Baik & Baik \\
\hline & & Sekali & Sekali & Sekali & Sekali & Sekali & Sekali & Sekali & Sekali & Sekali & Sekali & Sekali \\
\hline \multirow{2}{*}{6} & \multirow{2}{*}{ Servic } & Baik & Baik & Baik & Baik & Baik & Baik & Baik & Baik & Baik & Baik & Baik \\
\hline & & Sekali & Sekali & Sekali & Sekali & Sekali & Sekali & Sekali & Sekali & Sekali & Sekali & Sekali \\
\hline
\end{tabular}


Jurnal Keolahragaan 4 (1), April 2016 - 81

Riza Efriyanti, Sumaryanti

Tabel 8. Uji Keefektifan

\begin{tabular}{clccccc}
\hline No & Permainan & Thitung & Df & Ttabel & Sig & Keterangan \\
\hline 1 & $\begin{array}{l}\text { Temukan teman } \\
\text { Pretestt-Posttest }\end{array}$ & 19,674 & 21 & 2,079 & 0,000 & Efektif \\
2 & $\begin{array}{l}\text { Balpin } \\
\text { Pretestt-Posttest }\end{array}$ & 36,585 & 21 & 2,079 & 0,000 & Efektif \\
3 & $\begin{array}{l}\text { Kereta Suara } \\
\text { Pretestt-Posttest }\end{array}$ & 24,974 & 21 & 2,079 & 0,000 & Efektif \\
4 & $\begin{array}{l}\text { Halangan Bunyi } \\
\text { Pretestt-Posttest }\end{array}$ & 23,975 & 21 & 2,079 & 0,000 & Efektif \\
5 & $\begin{array}{l}\text { Balon Zig-zag } \\
\text { Pretestt-Posttest }\end{array}$ & 38,236 & 21 & 2,079 & 0,000 & Efektif \\
6 & $\begin{array}{l}\text { Lingkaran Ceria } \\
\text { Pretestt-Posttest }\end{array}$ & 26,720 & 21 & 2,079 & 0,000 & Efektif \\
\hline
\end{tabular}

Berdasarkan Tabel 3 hasil penilaian observasi keenam model permainan untuk pembelajaran kinestetik pada anak tunanetra maka dapat disimpulkan bahwa semuanya keenam model permainan tersebut "sangat baik" dilaksanakan oleh guru di sekolah. Sedangkan hasil penilaian alat permainan untuk pembelajaran kinestetik disajikan pada Tabel 4. Hasil dari Tabel 4 mengenai hasil penilaian alat model permainan untuk pembelajaran kinestetik pada anak tunanetra, dari hasil pengamatan performance, information, ekonomic, control, effecincy maka dapat disimpulkan bahwa alat model permainan untuk pembelajaran kinestetik pada anak tunanetra "sangat baik" untuk digunakan di sekolah.

Dari hasil uji skala kecil semua model permainan untuk pembelajaran kinestetik pada anak tunanetra dapat dilaksanakan dan mendapatkan beberapa saran agar adanya revisi uji coba skala kecil. Hasil uji skala kecil yang dilakukan oleh 4 ahli dan 2 orang guru didapatkan pengembangan model permainan untuk pembelajaran kinestetik pada anak tunanetra berada pada katagori "sangat baik". Dari hasil tersebut selanjutnya akan diuji cobakan pada tahap berikutnya yaitu uji coba skala besar. Uji coba produk skala besar dilakukan kepada 22 anak, dari 3 sekolah yang ada di DIY yaitu SLB-A Yaketunis, SLB Negri 1 Bantul, dan SLB Negri Kulon Progo. Selanjutnya hasil penilaian kuisioner model permainan disajikan pada Tabel 5.

Berdasarkan Tabel 5 hasil penilaian kuisioner keenam model permainan untuk pembelajaran kinestetik pada anak tunanetra yang dilakukan oleh 6 orang guru maka dapat disimpulkan bahwa semuanya keenam model permainan tersebut "sangat baik" dilaksanakan oleh guru di sekolah. Selanjutnya hasil penilai- an observasi yang telah dilakukan disajikan dalam bentuk Tabel 6 .

Berdasarkan Tabel 6, hasil penilaian observasi keenam model permainan untuk pembelajaran kinestetik pada anak tunanetra yang dilakukan oleh 6 orang guru maka dapat disimpulkan bahwa semuanya keenam model permainan tersebut "sangat baik" dilaksanakan oleh guru di sekolah. Selanjuntya hasil penilaian alat model permainan akan disajikan dalam Tabel 7.

Hasil dari Tabel 7, mengenai hasil penilaian alat model permainan untuk pembelajaran kinestetik pada anak tunanetra. Hasil pengamatan performance, information, ekonomic, control, effecincy, and service yang dilakukan oleh 6 orang guru maka dapat disimpulkan bahwa alat model permainan untuk pembelajaran kinestetik pada anak tunanetra "sangat baik" untuk digunakan di sekolah.

Dari hasil uji skala besar semua model permainan untuk pembelajaran kinestetik pada anak tunanetra dapat dilaksanakan. Hasil uji skala besar yang dilakukan oleh 6 orang guru didapatkan pengembangan model permainan untuk pembelajaran kinestetik pada anak tunanetra berada pada katagori "sangat baik". Dari hasil tersebut selanjutnya akan diuji cobakan pada tahap berikutnya yaitu uji keefektifan. Uji keefektifan dilakukan untuk melihat efektifitas dari keenam model permainan yang di uji cobakan pada anak tunanetra. hasil uji keefektifan dituangkan dalam Tabel 8 .

Berdasarkan perhitungan Tabel 8, hasil dari uji |t hitung| untuk pretestt dan posttest pada permainan temukan teman $=19,674>\mathrm{t}$ tabel $(0,05: 21)=2,079$ atau dengan membandingkan nila signifikansi lebih kecil dari taraf kesalahan $(0,05)$ maka dapat disimpulkan bahwa terdapat perbedaan antara pretestt dan posttest. Hasil dari uji |t hitung| 
untuk pretest dan posttest pada permainan balpin $=36,585>\mathrm{t}$ tabel $(0,05: 21)=2,079$ atau dengan membandingkan nila signifikansi lebih kecil dari taraf kesalahan $(0,05)$ maka dapat disimpulkan bahwa terdapat perbedaan antara pretest dan posttest. Hasil dari uji |t hitung| untuk pretest dan posttest pada permainan kereta suara $=24,974>\mathrm{t}$ tabel $(0,05: 21)=2,079$ atau dengan membandingkan nilaisignifikansi lebih kecil dari taraf kesalahan $(0,05)$ maka dapat disimpulkan bahwa terdapat perbedaan antara pretest dan posttest. Hasil dari uji $\mid \mathrm{t}$ hitung| untuk pretest dan posttest pada permainan halangan bunyi $=23,975>\mathrm{t}$ tabel $(0,05: 21)=$ 2,079 atau dengan membandingkan nila signifikansi lebih kecil dari taraf kesalahan $(0,05)$ maka dapat disimpulkan bahwa terdapat perbedaan antara pretest dan posttest. Hasil dar uji $\mathrm{tt}$ hitung| untuk pretest dan posttest pada permainan balon zig-zag $=38,236>\mathrm{t}$ tabel $(0,05: 21)=$ 2,079 atau dengan membandingkan nila signifikansi lebih kecil dari taraf kesalahan $(0,05)$ maka dapat disimpulkan bahwa terdapat perbedaan antara pretest dan posttest. Hasil dari uji $\mid \mathrm{t}$ hitung| untuk pretest dan posttest pada permainan lingkaran ceria $=26,720>t$ tabel $(0,05: 21)=$ 2,079 atau dengan membandingkan nila signifikansi lebih kecil dari taraf kesalahan $(0,05)$ maka dapat disimpulkan bahwa terdapat perbedaan antara pretest dan posttest.

\section{Pembahasan}

Berdasarkan hasil uji skala kecil dan skala besar keenam model yaitu (1) temukan teman; (2) balpin; (3) kereta suara; (4) halangan bunyi; (5) balon zig-zag; dan (6) lingkaran ceria, dapat dilaksanakan dengan "sangat baik". Maka dengan demikian dapat disimpulkan bahwa keenam model permainaan untuk pembelajaran kinestetik dapat dilaksananakan dengan sangat baik (efektif, efesien, aman, dan menyenangkan). Dari hasil uji keefektifan keenam model permainan untuk pembelajaran kinestetik pada anak tunanetra telah didapat bahwa skor rata-rata posttest lebih tinggi dari skor rata-rata pretestt. Maka dapat dinyatakan bahwa model permainan untuk pembelajaran kinestetik efektif digunakan untuk meningkatkan hasil belajar kinestetik. Hasil dari uji efektifitas penelitian skala besar terlihat semua permainan mengalami peningkatan. Peningkatan yang terjadi tidak terlepas dari adanya proses latihan dan pengulangan. Menurut Soegiarto (2002, p.4) latihan merupakan proses yang sistematis dari berlatih, yang dilakukan secara berulang-ulang dengan kian hari kian meningkat dengan metode yang memiliki tujuan. Adanya pengulangan keenam permainan tersebut membuat peningkatan kemampuan pada anak tunanetra. Menurut Sumaryanti., Kushartanti, \& Ambardhini (2010, p.4) perinsip sebuah latihan salah satunya adalah prinsip beragam yaitu kebosanan dalam berlatih merupakan fenomena yang paling sering dikeluhkan oleh pelaku olahraga. Perlu dilakukan variasi dalam latihan baik jenis, metoda maupun suasana berlatih. Keenam permainan yang telah dikembangkan efektif untuk meminimalisir kebosana pada anak-anak tunanera, karena permainan tersebut memenuhi unsur menyenagkan dan dilakukan diluar ruangan kelas.

\section{Keterbatasan Penelitian}

Adapun keterbatasan yang dialami selama melakukan penelitian antara lain yaitu: (1) Perlu adanya kajian yang lebih luas dan mendalam terkait permainan untuk pembelajaran kinestetik. Hal ini terkait dengan permainan yang dihadirkan ke dalam aktivitas permainan untuk anak tunanetra masih terbatas, (2) Terbatasnya sekolah-sekolah luar biasa khususnya bagian A untuk tunanetra yang ada di DIY, sehingga sedikit menghambat penelitian, (3) Masih banyak sekolah yang tidak memiliki lapangan yang luas sehingga proses pelaksanaan permainan harus dilakukan di lapangan yang seadanya atau mencari lapangan yang berada sedikit jauh dari sekolah, dan (4) Keterbatasan guru yang membantu sehingga penelitian harus dilakukan dengan waktu yang lumayan lama, sehingga memerlukan waktu khusus apabila akan melakukan proses penelitian.

\section{SIMPULAN DAN SARAN}

\section{Simpulan Tentang Produk}

Model permainan untuk pembelajaran kinestetik pada anak tunanetra yaitu: (1) temukan teman; (2) balpin; (3) kereta suara; (4) halangan bunyi; (5) balon zig-zag; dan (6) lingkaran ceria, sangat sesuai untuk kinestetik dan karakteristik pembelajaran untuk anak tunantra. Berdasarkan validasi yang dilakukan oleh 4 orang ahli menyatakan bahwa model permainan: (1) temukan teman; (2) balpin; (3) kereta suara; (4) halangan bunyi; (5) balon zigzag; dan (6) lingkaran ceria, tersebut baik untuk pembelajaran kinestetik pada anak tunanetra.

Berdasarkan uji coba skala kecil yang dilakukan oleh dua orang guru menyatakan 
pelaksanaan model permainan: (1) temukan teman; (2) balpin; (3) kereta suara; (4) halangan bunyi; (5) balon zig-zag; dan (6) lingkaran ceria, tersebut mudah, efektif dan efesien untuk dilaksanakan. Begitu juga pada saat uji coba skala besar yang dilakukan oleh enam orang guru menyatakan bahwa model permainan: (1) temukan teman; (2) balpin; (3) kereta suara; (4) halangan bunyi; (5) balon zig-zag; dan (6) lingkaran ceria, mudah untuk dilaksanakan.

Berdasarkan uji keefektifan terhadap model permainan: (1) temukan teman; (2) balpin; (3) kereta suara; (4) halangan bunyi; (5) balon zig-zag; dan (6) lingkaran ceria, model permainan dinyatakan efektif untuk meningkatkan pembelajaran kinestetik.

\section{Saran Pemanfaatan Produk}

Bagi anak tunanetra, agar terus belajar dan bereksplorasi dengan lingkungan luar ruangan karena pada hakikatnya tumbuh kembang anak khususnya ranah kinestetik akan lebih optimal jika dilakukan di luar ruangan. Disarankan juga bagi anak tunanetra untuk memanfaatkan model-model permainan gerak dan salah satu yang menjadi referensinya adalah permainan untuk pembelajaran kinestetik.

Bagi guru-guru, agar menambah kegiatan di luar ruangan untuk melatih kinestetik anakanak tunanetra dan salah satu dari banyak pilihan permainannya adalah permainan untuk pembelajaran kinestetik.

Bagi akademisi selanjutnya, perlu adanya kajian-kajian dan pengembangan-pengembangan lebih lanjut untuk menambah khasanah permaina untuk pembelajaran kinestetik, agar dapat menunjang proses belajar dan bermain untuk anak tunanetra yang sesuai dengan kurikulum yang berlaku. Selain itu perlu ditambah penelitian yang sesuai dan penambahan jumlah sampel.

\section{DAFTAR PUSTAKA}

Al-Fatah. H. (2007). Analisis dan perancangan sistem informasi. Yogyakarta: STMIK Amikom.

Bell, S. (2005). Design for outdoor recreation. London: Spon Press.

Borgesa, A.J \& Toméb, D. (2014). Teaching music to blind children: new strategies for teaching through interactive use of musibraille software. Jurnal International Conference On Software Development And Technologies For
Enhancing Accessibility And Fighting Info-Exclusion. 27, 19-27.

Borg, W. R \& Gall, M. D. (2007). Educational research: an indtroduction fourth edition. New york: Longman.

Daryanto, H (2005). Evaluasi pendidikan. Jakarta: Rineka Cipta.

Gardner, H. (2001). Multiple intelligences, (terjemahan oleh Alexander Sindoro). Cambridge, Harvard University, (Buku Asli Diterbitkan Tahun 1987).

Huda, M (2014). Model-model pengajaran dan pembelajaran. Yogyakarta: Pustaka belajar.

Hurwitz, A.K. (2008). A review of special education law. Jurnal Pediatric Neurology, 39, 147-154.

Imbiriba, A.L.,et all. (2006). Motor imagery in blind subjects: The influence of the previous visual experience. Jurnal Neuroscience Letters, 400, 181-185.

Kurtz, A.L. (2008), Understanding motor skills in children with dyspraxia, ADHD, autism, and other learning disabilities a guide to improving coordination. London: Jessica Kingsley Publishers.

Raisatun, N. (2012). Seabrek games asyikedukatif untuk mengajar paud/tk. Yogyakarta: DIVA Press.

Reniq. (2009). Latihan kecerdasan kinestetik terhadap gerak motorik penyandang tuna netra. Malang: Universitas Negri Malang.

Robert, M. G (2001). The Conditions of learning. HOLT: New York.

Smith, D.J. (2006). Inklusi sekolah ramah untuk semua. (Terjemahan Mohamad Sugiarmin). New York: Wodsworth Publishing Company. (Buku asli diterbitkan tahun 1998).

Sumaryanti., Kushartanti, B.M.W., \& Ambardhini, R.L. (2010). Pengembangan model pembelajaran jasmani adaptif untuk optimalisasi otak anak tunagrahita. Jurnal Kependidikan, Vol. 40, 29-44.

Sumiati \& Asra (2009). Teori pembelajaran. Yogyakarta: FIK UNY. 
Jurnal Keolahragaan 4 (1), April 2016 - 84

Riza Efriyanti, Sumaryanti

Sunanto. J. (2005). Mengembangakan potensi anak berkelainan penglihatan. Jakarta: Departemen Pendidikan Nasional Direktoral Jenderal Pendidikan Tinggi Direktorat Pembinaan Pendidikan Tenaga Kependidikan dan Ketenagaan Perguruan Tinggi.

Surya, M. (2002). Pisikologi pembelajaran dan pengajaran. Bandung PBB-IKIP: Bandung
Suyanto, M. (2004). Analisis dan desain aplikasi multimedia untuk pemasaran. Yogyakarta: STMIK Amikom.

Tarigan, B. (2000). Penjaskes adaptif. Jakarta: Direktorat Jenderal Pendidikan Dasar dan Menengah Bagian Proyek Penataran guru SLTP Setara D-III.

Widjaya, A (2013). Bentuk-bentuk tunanetra \& strategi pembelajaranya. Yogyakarta: Javalitera. 